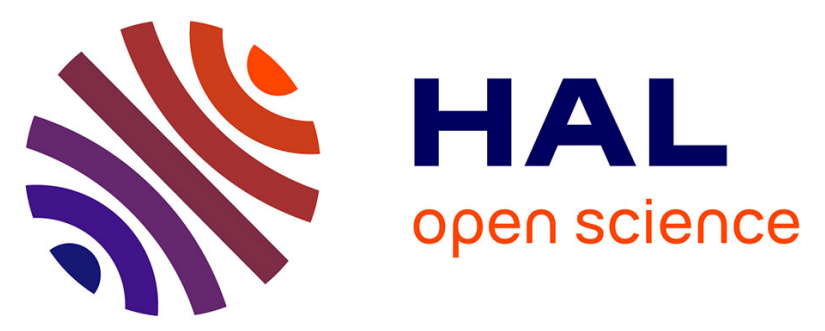

\title{
Factor Xa stimulates fibroblast procollagen production, proliferation, and calcium signaling via PAR1 activation
}

Olivier P. Blanc-Brude, Fabienne Archer, Patricia Leoni, Claudia Derian, Steven Bolsover, Geoffrey J. Laurent, Rachel C. Chambers

\section{- To cite this version:}

Olivier P. Blanc-Brude, Fabienne Archer, Patricia Leoni, Claudia Derian, Steven Bolsover, et al.. Factor Xa stimulates fibroblast procollagen production, proliferation, and calcium signaling via PAR1 activation. Experimental Cell Research, 2005, 304 (1), pp.16-27. 10.1016/j.yexcr.2004.10.021 . hal02682200

\section{HAL Id: hal-02682200 \\ https://hal.inrae.fr/hal-02682200}

Submitted on 1 Jun 2020

HAL is a multi-disciplinary open access archive for the deposit and dissemination of scientific research documents, whether they are published or not. The documents may come from teaching and research institutions in France or abroad, or from public or private research centers.
L'archive ouverte pluridisciplinaire HAL, est destinée au dépôt et à la diffusion de documents scientifiques de niveau recherche, publiés ou non, émanant des établissements d'enseignement et de recherche français ou étrangers, des laboratoires publics ou privés. 


\title{
Factor Xa stimulates fibroblast procollagen production, proliferation, and calcium signaling via $\mathrm{PAR}_{1}$ activation
}

\author{
Olivier P. Blanc-Brude ${ }^{\mathrm{a}, *}$, Fabienne Archer $^{\mathrm{b}}$, Patricia Leoni ${ }^{\mathrm{a}}$, Claudia Derian ${ }^{\mathrm{c}}$, Steven Bolsover ${ }^{\mathrm{b}}$, \\ Geoffrey J. Laurent ${ }^{\mathrm{a}}$, Rachel C. Chambers ${ }^{\mathrm{a}}$ \\ ${ }^{\mathrm{a}}$ Royal Free and University College London Medical School, Centre for Cardiopulmonary Biochemistry and Respiratory Medicine, 5 University Street, \\ London WC1E 6JJ, UK \\ ${ }^{\mathrm{b}}$ University College London Department of Physiology, Bolsover Laboratory, Gower Street, London WC1E 6BT, UK \\ ${ }^{\mathrm{c} J o h n s o n}$ and Johnson Pharmaceutical Research and Development, LLC, Welsch and McKean roads, Spring House, PA 19477-0776, USA
}

Received 16 April 2003, revised version received 15 September 2004

Available online 1 December 2004

\begin{abstract}
Fibroblast proliferation and procollagen production are central features of tissue repair and fibrosis. In addition to its role in blood clotting, the coagulation cascade proteinase thrombin can contribute to tissue repair by stimulating fibroblasts via proteolytic activation of proteinaseactivated receptor-1 $\left(\mathrm{PAR}_{1}\right)$. During hemostasis, the coagulation cascade proteinase factor $\mathrm{X}$ is converted into factor Xa. We have previously shown that factor Xa upregulates fibroblast proliferation via production of autocrine PDGF. In this study, we further examined the effects of factor $\mathrm{Xa}$ on fibroblast function and aimed to identify its signaling receptor. We showed that factor Xa stimulates procollagen promoter activity and protein production by human and mouse fibroblasts. This effect was independent of PDGF and thrombin production, but dependent on factor Xa proteolytic activity. We also showed that PAR $_{1}$-deficient mouse fibroblasts did not upregulate procollagen

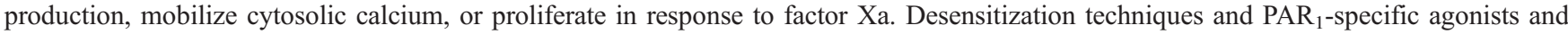
inhibitors were used to demonstrate that $\mathrm{PAR}_{1}$ mediates factor Xa signaling in human fibroblasts. This is the first report that factor Xa stimulates extracellular matrix production. In contrast with endothelial cells and vascular smooth muscle cells, fibroblasts appear to be the only cell type in which the effects of factor Xa are mediated mainly via $\mathrm{PAR}_{1}$ and not $\mathrm{PAR}_{2}$. These findings are critical for our understanding of tissue repair and fibrotic mechanisms, and for the design of novel approaches to inhibit the profibrotic effects of the coagulation cascade without compromising blood hemostasis.
\end{abstract}

(C) 2004 Elsevier Inc. All rights reserved.

Keywords: Fibroblast; Coagulation; Factor Xa; $\mathrm{PAR}_{1}$; Tissue repair; Fibrosis; Procollagen; Proliferation

Abbreviations: $\left[\mathrm{Ca}^{2+}\right]_{\mathrm{i}}$, Cytosolic-free $\mathrm{Ca}^{2+}$ concentration; CTGF, Connective tissue growth factor; DEGR-ck, dansyl-Glu-Gly-Arg chloromethylketone dihydrochloride; EPR-1, Effector cell-protease receptor-1; HBS, HEPES-buffered saline; MAPK, Mitogen-activated protein kinase; $\mathrm{PAR}_{1}$, Proteinase-activated receptor-1; PDGF, Platelet-derived growth factor; PTX, Pertussis toxin.

* Corresponding author. Present address: Olivier Blanc-Brude, INSERM Unit 541, Hôpital Lariboisière, 41 Boulevard de la Chapelle, 75010 Paris, France. Fax: +33142813128.

E-mail address: olivier.blanc-brude@larib.inserm.fr (O.P. Blanc-Brude)

\section{Introduction}

Fibroblast proliferation and extracellular matrix production are central features of normal tissue repair and pathological tissue fibrosis. Tissue fibrosis is the end stage of a heterogenous group of disorders that can affect many organs, including the lung [1], the kidney [2], and the liver [3]. Excessive fibroblast proliferation and collagen deposition are common to these diseases. Many normal responses to tissue injury are recapitulated in tissue fibrosis, but they are deregulated, exacerbated, and abnormally sustained. Eventually, the accumulation of connective tissue, mainly collagen types I and III, compromises the organ's function and often leads to premature death. 
In pulmonary fibrosis, increased levels of classical cytokines and growth factors, such as transforming growth factor- $\beta_{1}$, platelet-derived growth factor (PDGF), and insulin growth factor-1 promote fibroblast function [4]. However, blood coagulation and the dramatic activation of the coagulation cascade proteinase thrombin have also been extensively documented in association chronic lung injury [5], in pulmonary fibrosis associated with scleroderma, and in interstitial pulmonary fibrosis [6,7]. Activation of the coagulation cascade is particularly relevant to the lung and organs where the interstitial compartment is in close contact with an extensive microvascular bed. Persistent activation of the coagulation cascade is thought to result from an imbalance between pro- and anticoagulant factors. For instance, bronchoalveolar lavage (BAL) fluid from patients with acute respiratory distress syndrome (ARDS) contains elevated levels of factor VIIa, a factor that initiates blood coagulation [8]. High levels of factor Xa are also generated following lung injury [8], during pulmonary fibrosis $[9,10]$, and in a variety of fibrotic and infectious conditions [11,12]. On the other hand, abnormally low levels of anti-coagulant factors such as antithrombin III have been observed in ARDS, resulting in increased procoagulant activity [13].

There is increasing evidence that the coagulation cascade proteinase thrombin contributes to the pathogenesis of lung fibrosis. Thrombin stimulates fibroblast recruitment [14] and proliferation $[15,16]$, increases procollagen production in vitro [17], and accelerates tissue fibrosis [18]. Thrombin can activate several seven transmembrane domain $G$ protein-coupled cell surface receptors $[19,20]$ termed proteinase-activated receptors $\left(\mathrm{PAR}_{1}, \mathrm{PAR}_{3}\right.$ and $\left.\mathrm{PAR}_{4}\right)$. $\mathrm{PAR}_{1}$ is the principal receptor for thrombin in fibroblasts $[17,20,21]$ and its activation leads to autocrine fibroblast simulation via the production of PDGF [16] and possibly CTGF [22]. We recently obtained the first evidence that direct thrombin inhibition attenuates connective tissue deposition in a model of experimental pulmonary fibrosis [23], supporting the idea that thrombin contributes to tissue fibrosis [24]. However, little is known about the potential role of other coagulation cascade proteinases.

Factor Xa plays a critical role at the point of convergence of the intrinsic and extrinsic coagulation pathways, by converting prothrombin into active thrombin during blood coagulation $[11,12]$. We have recently shown that factor Xa is also a potent stimulator of PDGF-A expression and a mitogen for human lung fibroblasts in vitro, and that factor $\mathrm{Xa}$ acts independently of thrombin generation [25]. In contrast, coagulation cascade proteinases activated upstream of factor Xa, such as factor IXa and VIIa, had no significant effect at physiological concentrations. We further showed that ligation of effector cell protease receptor-1 (EPR-1) by factor Xa enhances its mitogenic effect. However, the factor $\mathrm{Xa}$ receptor that transduces its mitogenic signal remains unknown. In pioneering studies, Riewald and Ruf [26] recently reported that factor $\mathrm{Xa}$ can activate $\mathrm{PAR}_{1}$ and $\mathrm{PAR}_{2}$ in heterologous transfection systems. PAR activation by factor Xa was greatly enhanced by cotransfection of tissue factor and the presence of factor VIIa, presumably associating at the cell surface. This group also showed that factor Xa can stimulate gene expression in HeLa cells that express $\mathrm{PAR}_{1}$ and not $\mathrm{PAR}_{2}$ [27].

In this study, we aimed to further investigate the profibrotic effects of factor $\mathrm{Xa}$ and begin to characterize the signaling receptors responsible for these effects in fibroblasts. Our experiments showed that factor Xa stimulates fibroblast procollagen production in human and mouse fibroblasts and put in light the essential role of $\mathrm{PAR}_{1}$ in these events, even in the presence of other factor $\mathrm{Xa}$ receptors such as $\mathrm{PAR}_{2}$ and EPR-1.

\section{Materials and methods}

\section{Materials}

Purified Russel's viper venom-activated human factor $\mathrm{Xa}$, pertussis toxin (PTX) and dansyl-Glu-Gly-Arg chloromethylketone dihydrochloride (DEGR-ck) were from Calbiochem-Novabiochem UK Ltd. (Nottingham, UK). Catalytically inactivated factor Xa (DEGR-factor Xa) was prepared by Dr C. Goodwin (National Heart and Lung Institute, London, UK) by incubation of factor Xa with DEGR-ck until no proteolytic activity remained. Excess DEGR-ck was removed by extensive dialysis and the purity of DEGR-factor Xa was assessed by conventional SDSPAGE. Human $\alpha$-thrombin was purchased from Sigma Ltd. (Poole, UK), human airway mast cell tryptase was from Europa Bioproducts Ltd. (Wicken, UK) and the specific cell-permeant intracellular $\mathrm{Ca}^{2+}$ chelator BAPTA-AM was purchased from Molecular Probes Europe BV (Leiden, The Netherlands). Porcine TGF- $\beta 1$, recombinant PDGF-AB were from R\&D Systems (Minneapolis, MN). The specific PAR1 agonist TFLLR [28] was synthesized as an amidated peptide by Professor R. Mecham (University of Washington, St. Louis, MO, USA). The selective PAR $_{1}$ antagonist RWJ-58259 was previously described by Derian et al. [29]. Recombinant tick anticoagulant peptide (rTAP) [30] was a kind gift from Dr. M. Scully (National Heart and Lung Institute, London, UK) and originally prepared by Dr. G. Vlasuk (Corvas International, San Diego, CA). Antistasin core peptide D-Arg ${ }^{32}-\mathrm{Pro}^{38}$ (ASN peptide) [31] was purchased from Bachem (Saffron Walden, UK). Those well-characterized inhibitors are increasingly used to specifically inhibit factor Xa while leaving thrombin activity intact [25-27].

Human fetal, mouse PAR ${ }_{I}$-deficient fibroblasts and tissue culture

Human fetal lung fibroblasts (HFL-1, ref. CCL-153) were obtained from ATCC (Rockville, MD, USA) and used 
at passages below 20. Wild-type and $\mathrm{PAR}_{1}$-deficient mouse lung fibroblasts [20] were kind gifts from Dr S. Coughlin (Cardiovascular Research Institute, University of California, San Francisco, CA, USA). Cells were routinely cultured at $37^{\circ} \mathrm{C}$ in DMEM supplemented with $10 \%$ neonatal calf serum and standard antibiotics. For proliferation and DNA synthesis experiments, fibroblasts were seeded in 96-well plates $(5000 \mathrm{cells} / 100 \mu \mathrm{l} / \mathrm{well})$, grown to $75 \%$ confluency for $24 \mathrm{~h}$ in $5 \%$ neonatal calf serum before treatment.

\section{DNA synthesis and proliferation assays}

Fibroblasts were grown to subconfluence, quiesced, and incubated in DMEM supplemented with test substances in the absence of serum. DNA synthesis was assayed by addition of $\left[{ }^{3} \mathrm{H}\right]$ thymidine $(2 \mu \mathrm{Ci} / \mathrm{ml})$ for the last $4 \mathrm{~h}$ of a 20 $\mathrm{h}$ incubation. DNA was collected, washed, and shaken in scintillation fluid overnight before radioactivity was evaluated. Fibroblast proliferation was assayed after $48 \mathrm{~h}$ of incubation using a colorimetric assay based on the uptake and elution of methylene blue dye [32] to reveal whether potential mitogens stimulate cell cycle progression through to cell division. Data were expressed as means \pm standard error of the mean (SEM) in percent stimulation above control. Statistical evaluation was performed using the unpaired Student's $t$ test. Significance was achieved when $P<0.05$.

\section{Immunoblotting}

Subconfluent mouse wild-type and PAR1-deficient lung fibroblasts in the absence of serum were lysed in $2 \%$ SDS. Weight-normalized aliquots $(80 \mu \mathrm{g})$ of whole cell lysates were boiled and separated in a $12 \%$ acrylamide gel under reducing conditions. Samples were electrophoresed at 150 $\mathrm{V}$ for $3 \mathrm{~h}$. Proteins were then electroblotted onto Immobilon membranes (Millipore Corp., Bedford, MA, USA) for $1 \mathrm{~h}$ at $0.8 \mathrm{~A}$. Membranes were blocked with $5 \%$ milk in Tris-buffered saline and incubated at $22^{\circ} \mathrm{C}$ for $2 \mathrm{~h}$ with $10 \mu \mathrm{g} / \mathrm{ml}$ of a sequence-specific anti-EPR-1 rabbit antibody (TAIL antibody) [33], followed by peroxidaseconjugated goat anti-rabbit IgG for $1 \mathrm{~h}$ (1:5000 dilution), and visualization with an enhanced chemiluminescence detection system.

\section{Single cell cytosolic $\mathrm{Ca}^{2+}$ spectrofluorometry}

Fibroblasts were plated in DMEM supplemented with $10 \%$ neonatal calf serum $(5000$ cells $/ \mathrm{ml})$ in hydrophilic Petriperm tissue culture plates (Heraeus Instruments $\mathrm{GmbH}$, Hanau, Germany), grown to $50 \%$ confluence, and loaded with the calcium indicator Fura-2 by incubation with $2 \mu \mathrm{M}$ Fura-2-AM plus $25 \mathrm{mg} / \mathrm{L}$ Pluronic F127 (Molecular Probes) for 30 min [34]. Cells were placed on the stage of an Axiovert 100TV fluorescence microscope (Carl Zeiss Ltd., Welwyn Garden City, UK) fitted with
Fucal 5.12c imaging system (TILL Photonics GmbH, Martinsreid, Germany). Cells were rinsed twice with HBS and test solutions were delivered by dish perfusion. $340 / 380 \mathrm{~nm}$ ratio pairs were acquired for 10 to 20 cells every $2 \mathrm{~s}$ for up to $4 \mathrm{~min}$. Cytosolic $\mathrm{Ca}^{2+}$ values were calculated using the standard calibration equation $\left[\mathrm{Ca}^{2+}\right]=$ $K_{\mathrm{d}}^{\mathrm{Ca} 2+} \times S \times\left(R-R_{\min }\right) /\left(R_{\max }-R\right)$ [35]. Individual $\mathrm{Ca}^{2+}$ transients obtained in all cells in each treatment group were averaged to obtain a single representative $\left[\mathrm{Ca}^{2+}\right]_{\mathrm{i}}$ curve used for comparison purposes. Variations in $\left[\mathrm{Ca}^{2+}\right]_{i}$ after stimulation were influenced by the number of responsive cells, the peak increase in $\left[\mathrm{Ca}^{2+}\right]_{i}$, and the average increase over the complete stimulation period. We analyzed all three parameters since any variation in $\left[\mathrm{Ca}^{2+}\right]_{\mathrm{i}}$ may significantly affect cell function, and because individual proteinases stimulated either delayed non-synchronous responses or immediate synchronous responses. In such conditions, we and others have shown that factor Xa signaling via cytosolic $\mathrm{Ca}^{2+}$ transients and cGMP production occurs independently of thrombin generation $[25,34,36]$.

To investigate the effects of receptor desensitization on calcium responses, fibroblasts were washed twice with PBS to remove serum, pretreated with factor Xa $(25 \mathrm{nM})$, thrombin $(25 \mathrm{nM})$ or agonist vehicle (HEPES-buffered saline, HBS) in serum-free conditions for $90 \mathrm{~min}$. Fura-2 was loaded during the last $30 \mathrm{~min}$. Our desensitization protocol (25 $\mathrm{nM}$ proteinase for $90 \mathrm{~min}$ ) was selected after determination of the minimal thrombin concentration (25 $\mathrm{nM})$ and incubation time (60 min) necessary for total PAR $_{1}$ desensitization in human fibroblasts, as previously described in endothelial cells $[37,38]$.

To inhibit $\mathrm{PAR}_{1}$ specifically, fibroblasts were plated on glass cover slips, pretreated with HBS or the selective PAR $_{1}$ antagonist RWJ-58259 for 5 min before stimulation with factor Xa or thrombin $(25 \mathrm{nM})$. For dosage, we selected a concentration of RWJ-58259 $(1 \mu \mathrm{M})$ sufficient to entirely inhibit thrombin-induced proliferation of smooth muscle cells [29]. For comparative purposes, cytosolic $\mathrm{Ca}^{2+}$ mobilization was expressed in \% relative calcium rise above basal levels in HBS-treated controls.

\section{Determination of procollagen production}

Procollagen production was determined as described elsewhere $[39,40]$. Briefly, fibroblasts were grown to full confluence for 5 days. Media were replaced with serumfree DMEM supplemented with $50 \mu \mathrm{g} / \mathrm{ml}$ ascorbic acid and $0.2 \mathrm{mM}$ proline for $24 \mathrm{~h}$. These conditions of confluency and serum starvation that do not allow further significant proliferation. The cells were then treated with or without factor Xa, thrombin or TGF- $\beta_{1}$. After $48 \mathrm{~h}$, the cell layer and medium were harvested together (human fibroblasts) or separately (mouse fibroblasts) and proteins were ethanol-precipitated. Ethanol-insoluble proteins were separated from free amino acids by filtration, washed twice 
with ethanol, and hydrolyzed overnight in $6 \mathrm{M} \mathrm{HCl}$ at $110^{\circ} \mathrm{C}$. Hydrolysates were cleared with activated charcoal and filtered and derivatized with 4-chloro-7-nitrobenzofurazan (NBD-Cl) (Sigma). Hydroxyproline in ethanol-insoluble fractions was quantified by reverse-phase HPLC using a Beckman System Gold (Beckman, High Wycombe, Bucks., UK), and taken as an index of procollagen production. Data are expressed as nmol of hydroxyproline per well per $48 \mathrm{~h}$. Hydroxyproline associated with the cell layer at the onset of the experiment was subtracted from all values.

\section{Determination of procollagen- $\alpha_{1}(I)$ promoter activity}

For the analysis of procollagen- $\alpha 1(\mathrm{I})$ transcriptional activity, a human procollagen- $\alpha_{1}(\mathrm{I})$ promoter-reporter construct was transiently transfected into approximately $90 \%$ confluent human fetal lung fibroblasts, mouse wild type, and $\mathrm{PAR}_{1}$-deficient lung fibroblasts. The construct was a kind gift from Dr Raghow (University of Tennessee, USA) and contained 804 bp of the procollagen- $\alpha_{1}(\mathrm{I})$ promoter region upstream from the initiation site, including $117 \mathrm{bp}$ of the first intron coupled to the luciferase coding sequence $[41,42]$. This promoter was selected as it gave maximal responses to TGF- $\beta_{1}$ in our assay conditions. The sequence identity for human and mouse type I collagen genes (COL1A1) is very high in these regions with several highly conserved cis-acting elements. This construct has previously been successfully employed to examine the transcriptional regulation of COL1A1 gene expression using mouse NIH3T3 fibroblasts [42]. The transfection efficiency, estimated with the number of positively stained cells after transfection with a control construct encoding the LacZ reporter gene, was estimated to be about $30 \%$. A novel peptide comprising an RGD moiety for integrin binding and a polylysine moiety for DNA binding (peptide-6), was used to enhance transfection efficiency [43]. Forty-microliter peptide-6 was mixed with $0.75 \mu \mathrm{l}$ lipofectin (Gibco BRL Life Technologies, Paisley, Scotland, UK), in $100 \mu \mathrm{l}$ OptiMEM (Gibco), and $0.5 \mu \mathrm{g}$ promoter-reporter construct DNA was mixed with $100 \mu \mathrm{l}$ OptiMEM. The two solutions were mixed for $45 \mathrm{~min}$ at RT, diluted to make a final volume of $500 \mu \mathrm{l}$ with OptiMEM before addition to the cells in 12 well plates for $6 \mathrm{~h}$. Cells were washed with PBS and placed in fresh DMEM with $10 \%$ serum overnight. Transfected cells were placed in fresh DMEM without serum, with or without additions for $24 \mathrm{~h}$. For catalytic site inhibition, factor Xa was incubated with rTAP or ASN for $2 \mathrm{~h}$ at $37^{\circ} \mathrm{C}$, or in combination with a polyclonal pan-specific neutralizing antibody directed against PDGF $(10 \mu \mathrm{g} / \mathrm{ml})$ to block the effects of the growth factor as described elsewhere [25]. Cells were lysed and aliquots $(10 \mu \mathrm{l})$ of the soluble fraction were added to $100 \mu \mathrm{l}$ luciferase substrate at RT. Chemiluminescence was measured immediately in triplicates with a TD-20/20 luminometer (Turner Designs,
Promega UK, Southampton, UK) using a Luciferase Assay System (Promega). Each experiment was repeated twice and the data expressed in relative light units (RLU).

\section{Results}

\section{Factor Xa stimulates fibroblast procollagen production}

We determined the effects of factor Xa on procollagen$\alpha_{1}(\mathrm{I})$ promoter activity and procollagen protein production in human lung fibroblasts. Fig. 1A shows that factor Xa stimulated procollagen protein production by up to $125 \%$ in fully confluent and quiesced human fibroblasts in vitro over $48 \mathrm{~h}$. The effect of factor Xa was dose-dependent and peaked at $25 \mathrm{nM}(P<0.01)$. Thrombin $(25 \mathrm{nM})$ and TGF$\beta_{1}(1 \mathrm{ng} / \mathrm{ml})$ stimulated rates of procollagen production by about $200 \%$ and $250 \%$, respectively. In contrast, coagulation factor IXa had no significant effect.

\section{Factor Xa stimulates fibroblast procollagen- $\alpha_{1}(I)$ promoter} activity

The effect of factor Xa on procollagen- $\alpha_{1}(\mathrm{I})$ promoter activity was evaluated using a luciferase-linked procollagen$\alpha_{1}(\mathrm{I})$-promoter construct transiently transfected into human fetal lung fibroblasts. Fig. 1B shows that factor Xa (25 nM) upregulated procollagen- $\alpha_{1}(\mathrm{I})$ promoter activity by almost 5 -fold in serum-starved confluent human fibroblasts. In contrast, PDGF-AB $(10 \mathrm{ng} / \mathrm{ml})$ was a poorer stimulus for procollagen- $\alpha_{1}(\mathrm{I})$ gene transcription, stimulating less than a doubling in promoter activity. Since we have previously reported that factor Xa can stimulate PDGF-A expression in fibroblasts, we determined the effect of a polyclonal panspecific neutralizing antibody directed against PDGF at a concentration $(10 \mu \mathrm{g} / \mathrm{ml})$ necessary to completely block the mitogenic effect of factor Xa in our cells [25]. The neutralizing anti-PDGF antibody completely blocked the effect of PDGF-AB, but only reduced the effect of factor Xa by about $25 \%(P<0.01)$, (Fig. 1B). In order to determine the role of factor Xa catalytic activity, we used the highly specific inhibitors, rTAP and ASN peptide [30,31] which we have previously shown to block the mitogenic effect of factor Xa on human lung fibroblasts [25]. Fig. 1C shows that rTAP and ASN blocked factor Xa-stimulated procollagen- $\alpha_{1}(\mathrm{I})$ promoter activity by $60 \%$ and $40 \%$, respectively $(P<0.01)$.

\section{Procollagen- $\alpha_{I}(I)$ promoter activity and procollagen production in $P A R_{1}$-deficient mouse lung fibroblasts}

We next assessed the role of $\mathrm{PAR}_{1}$ in mediating the stimulation by factor $\mathrm{Xa}$ of procollagen- $\alpha_{1}(\mathrm{I})$ promoter activity in wild-type and $\mathrm{PAR}_{1}$-deficient mouse lung fibroblasts transfected with a procollagen- $\alpha_{1}(\mathrm{I})$-promoter reporter construct. Fig. 2A shows that TGF- $\beta_{1}(1 \mathrm{ng} / \mathrm{ml})$, 
factor $\mathrm{Xa}(25 \mathrm{nM})$ and thrombin $(25 \mathrm{nM})$ stimulated procollagen- $\alpha_{1}(\mathrm{I})$ promoter activity by about 3 - to 4 -fold over control levels in wild-type fibroblasts $(P<0.01$ for all). In $\mathrm{PAR}_{1}$-deficient fibroblasts, TGF- $\beta_{1}$ (positive control) [40] stimulated a similar increase in procollagen promoter activity $(P<0.01)$, but factor $\mathrm{Xa}$ and thrombin had no significant effect. In other experiments, wild-type and $\mathrm{PAR}_{1}$-deficient mouse lung fibroblasts were treated with factor Xa. Fig. 2B shows that procollagen production was increased by $45.5 \%$ over $48 \mathrm{~h}(P<0.01)$ by factor Xa in wild-type fibroblasts, whereas $\mathrm{PAR}_{1}$-deficient fibroblasts were unresponsive. Note that a significant difference in basal procollagen production

A

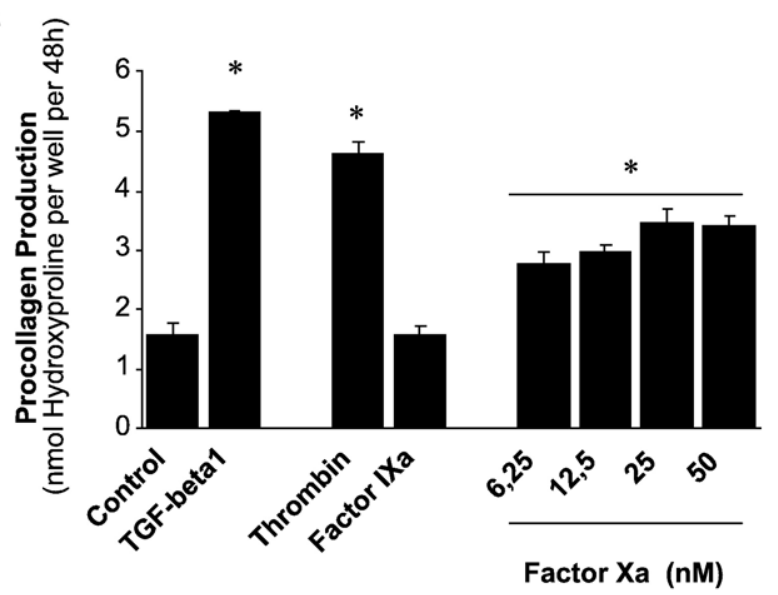

B

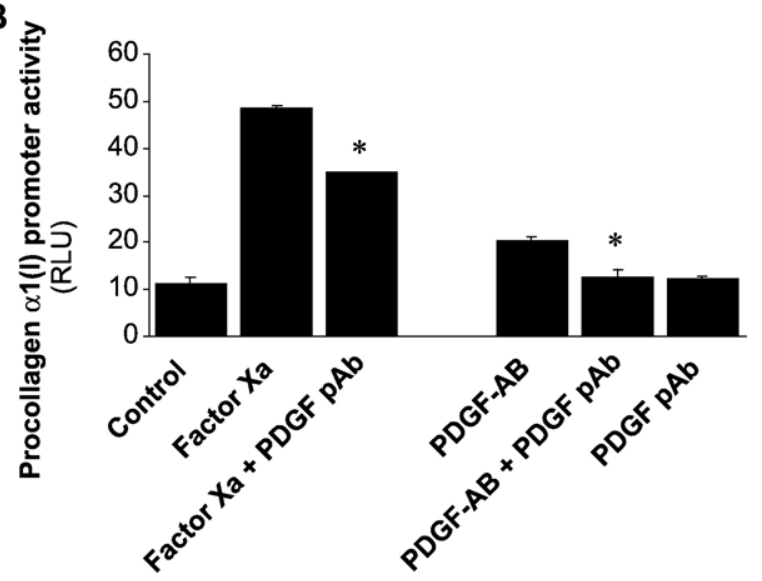

C

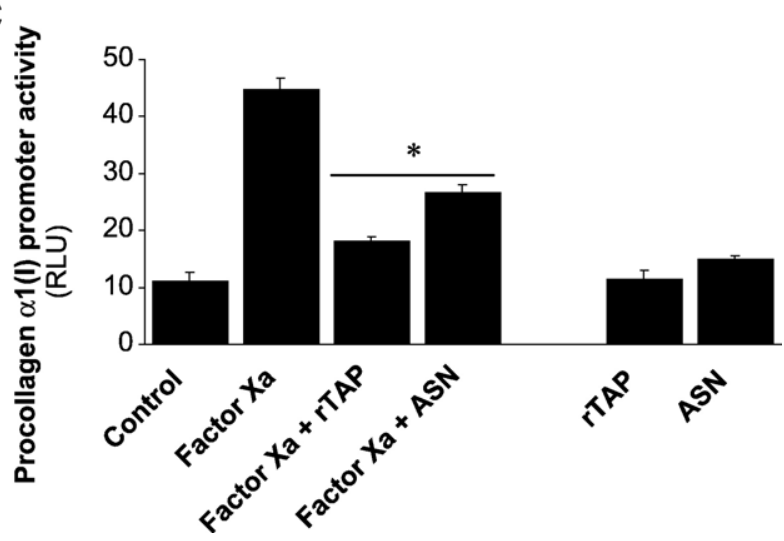

rates was observed between wild-type $(0.33 \mathrm{nmol} / \mathrm{well} / 48 \mathrm{~h})$ and $\mathrm{PAR}_{1}$-deficient fibroblasts $(7.11 \mathrm{nmol} /$ well $/ 48 \mathrm{~h})$. A difference in procollagen promoter activity was also observed (see legend to Fig. 2A). Since fibroblasts are known to be heterogeneous in their capacity to proliferate and produce collagen and other extracellular matrix proteins, this difference may arise from clonal selection during primary fibroblast isolation.

\section{Proliferation of PAR ${ }_{1}$-deficient mouse lung fibroblasts}

We also assessed proliferation and immediate transient cytosolic $\mathrm{Ca}^{2+}$ signals provoked by factor $\mathrm{Xa}$ in $\mathrm{PAR}_{1}$ deficient mouse lung fibroblasts in serum-free conditions. Factor Xa and thrombin stimulated a doubling in wild-type mouse fibroblast proliferation $(P<0.01)$, but $\mathrm{PAR}_{1-}$ deficient fibroblasts completely failed to respond (Fig. 3A). In contrast, mast cell tryptase, known to activate $\mathrm{PAR}_{2}$, stimulated proliferation equally in wild-type and $\mathrm{PAR}_{1}$ deficient fibroblasts $(45 \%$ increase; $P<0.01$ versus controls).

\section{Cytosolic $\mathrm{Ca}^{2+}$ signals in $P A R_{1}$-deficient mouse lung fibroblasts}

In wild-type mouse lung fibroblasts, factor Xa elicited a rise in cytosolic $\mathrm{Ca}^{2+}$ (60 cells evaluated per condition) $70 \mathrm{~s}$ after stimulation, reaching up to $310 \%$ above basal levels, (Fig. 3B). Thrombin elicited a $\mathrm{Ca}^{2+}$ rise $30 \mathrm{~s}$ after stimulation, reaching up to $800 \%$ above basal levels. In contrast, $\mathrm{PAR}_{1-}$ deficient fibroblasts showed greatly reduced responses. Cytosolic $\mathrm{Ca}^{2+}$ signals provoked by factor $\mathrm{Xa}$ and thrombin exhibited certain differences: the average $\mathrm{Ca}^{2+}$ signal

Fig. 1. Factor Xa stimulates fibroblast procollagen production. (Panel A) Procollagen production by human fibroblasts. Confluent human fetal lung fibroblasts were washed and incubated with either serum-free control medium, factor Xa $(6.25,12.5,25$ and $50 \mathrm{nM})$, thrombin $(25 \mathrm{nM})$, factor IXa $(25 \mathrm{nM})$, or TGF- $\beta_{1}(40 \mathrm{pM})$, for $48 \mathrm{~h}$ and harvested. Total hydroxyproline content was quantified by reverse-phase HPLC. Data are expressed as the mean of six replicates from a representative experiment that was repeated three times and expressed as nmol of hydroxyproline per well per $48 \mathrm{~h} \pm \mathrm{SEM}^{*} P<0.01 ; P$ values are calculated against control treatment. (Panel B) Procollagen- $\alpha_{1}(\mathrm{I})$ promoter activity in human fibroblasts. Serum-deprived confluent human fetal lung fibroblasts were transiently transfected with a human procollagen- $\alpha_{1}(\mathrm{I})$ promoter-luciferase reporter construct. The transfected cells were washed and incubated with factor Xa $(25 \mathrm{nM})$, PDGF-AB $(10 \mathrm{ng} / \mathrm{ml})$, or with a polyclonal pan-specific anti-PDGF neutralizing antibody $(15 \mu \mathrm{g} / \mathrm{ml})$ for $24 \mathrm{~h}$. Luciferase activity was determined as described in Materials and methods. Data are expressed as mean of three replicates in relative light units (RLU) \pm SEM from a representative experiment that was repeated twice. $* P$ values $<0.01$ against treatment without anti-PDGF blocking antibody. (Panel C) Procollagen$\alpha_{1}(\mathrm{I})$ promoter activity in human fibroblasts. The experimental protocol was as described for panel $\mathrm{B}$, but fibroblasts were transfected with the human procollagen- $\alpha_{1}(\mathrm{I})$ promoter-reporter construct were incubated with medium only, factor Xa (25 nM), rTAP (125 nM), or ASN (1 mM) for $24 \mathrm{~h}$. Data are expressed as mean of three replicates in relative light units (RLU) \pm SEM from a representative experiment that was repeated twice. ${ }^{*} P$ values $<0.01$ against treatment with factor Xa alone. 
triggered by factor Xa was modest in amplitude, and its onset was delayed compared with thrombin. However, factor $\mathrm{Xa}$ stimulated cytosolic $\mathrm{Ca}^{2+}$ signals in over $90 \%$ mouse wild-
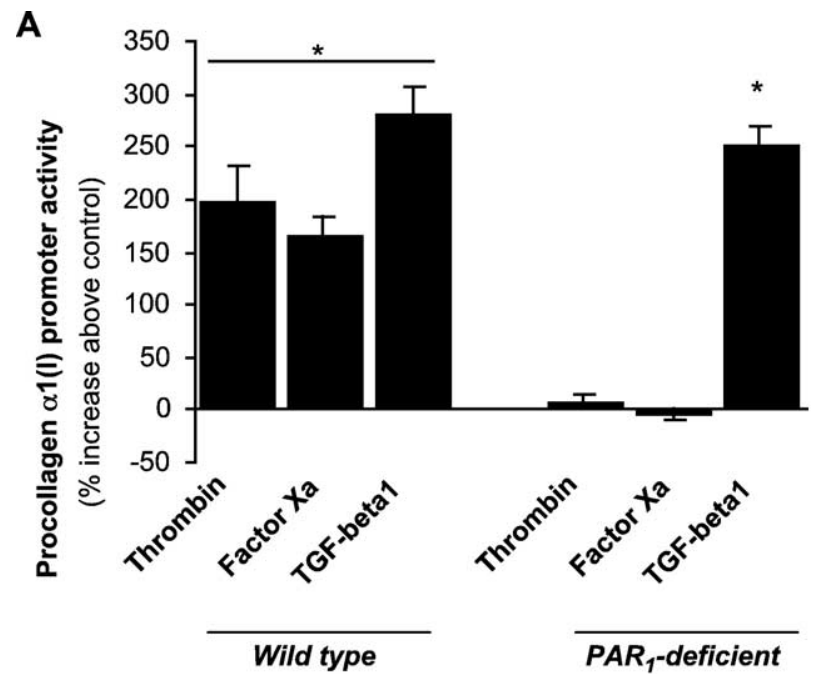

B
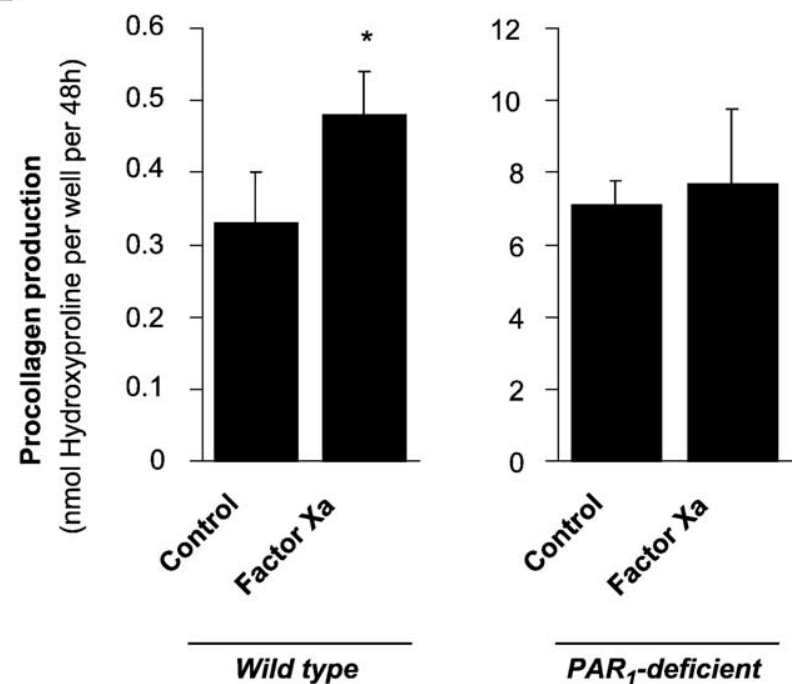

Fig. 2. $\mathrm{PAR}_{1}$ mediates factor $\mathrm{Xa}$ procollagen gene expression in mouse fibroblasts. (Panel A) Procollagen- $\alpha_{1}(\mathrm{I})$ promoter activity in $\mathrm{PAR}_{1}$-deficient mouse fibroblasts. The experimental protocol was as described in Fig. 1B, but experiments were performed with wild-type and $\mathrm{PAR}_{1}$-deficient fibroblasts transfected with the procollagen- $\alpha_{1}(\mathrm{I})$ promoter-reporter construct and incubated with medium only, TGF- $\beta_{1}(1 \mathrm{ng} / \mathrm{ml})$, factor Xa (25 $\mathrm{nM}$ ), or thrombin $(25 \mathrm{nM})$ for $24 \mathrm{~h}$. Data are expressed as mean of four replicates in $\%$ increase above controls \pm SEM from a representative experiment that was repeated twice. Data are presented in \% stimulation above control levels to facilitate comparisons. ${ }^{*} P$ values $<0.01$ against control treatment. (Data in Relative light units: Control, $22.0 \pm 1.6$, factor $\mathrm{Xa} 51.9 \pm 3.0$, thrombin $57.8 \pm 6.2$, TGF- $\beta_{1} 80.1 \pm 5.6$, in control fibroblasts. Control, $66.2 \pm 6.1$, factor Xa $62.9 \pm 5.2$, thrombin $69.0 \pm 3.2$, TGF- $\beta_{1} 173.6 \pm 9.7$, in PAR $_{1}$-deficient fibroblasts). (Panel B) Procollagen production in $\mathrm{PAR}_{1}$-deficient mouse fibroblasts. Experiments were performed with wild-type and $\mathrm{PAR}_{1}$-deficient fibroblasts incubated with medium only, TGF- $\beta_{1}(1 \mathrm{ng} / \mathrm{ml})$, factor Xa $(25 \mathrm{nM})$, or thrombin (25 $\mathrm{nM}$ ) for $48 \mathrm{~h}$. The data represent the amount of hydroxyproline associated with the cell layer and is expressed as the mean of six replicates in \% increase above controls \pm SEM from a representative experiment that was repeated twice. ${ }^{*} P$ values $<0.01$ against control treatment. type fibroblasts, compared to less than $10 \%$ for $\mathrm{PAR}_{1}$ deficient fibroblasts. Thrombin stimulated $\mathrm{Ca}^{2+}$ transients in $100 \%$ wild-type fibroblasts but none in $\mathrm{PAR}_{1}$-deficient fibroblasts, in agreement with previous observations [20].

\section{EPR-1 expression in PAR ${ }_{1}$-deficient mouse lung fibroblasts}

Since we have previously implicated EPR-1 in the mitogenic effects of factor Xa on human fibroblasts [25], we also investigated EPR-1 expression in mouse fibroblasts by Western blot analysis with a sequence-specific antibody directed against the cytoplasmic domain of the receptor. A predominant immunoreactive band of $65 \mathrm{kDa}$ corresponded to the molecular weight of human EPR-1 (Fig. 3C). The intensity of the EPR-1 band was comparable for wild-type and $\mathrm{PAR}_{1}$-deficient lung fibroblasts.

\section{Cytosolic $\mathrm{Ca}^{2+}$ signals in human lung fibroblasts}

To determine the role of $\mathrm{PAR}_{1}$ in factor Xa signaling in human fibroblasts, we studied the effects of factor Xa, catalytically inhibited factor Xa, thrombin and the highly specific $\mathrm{PAR}_{1}$ agonist peptide, TFLLR [28] on $\left[\mathrm{Ca}^{2+}\right]_{\mathrm{i}}$ in naive human fibroblasts. Fig. 4A shows that factor Xa provoked an average increase in $\left[\mathrm{Ca}^{2+}\right]_{\mathrm{i}}$ of $195 \%$ above basal levels over the monitoring period $(P<0.05)$. The peak increase in $\left[\mathrm{Ca}^{2+}\right]_{\mathrm{i}}$ reached $225 \%$ above basal levels about $50 \mathrm{~s}$ after stimulation. However, each $\mathrm{Ca}^{2+}$ transient in individual cells was only about $100 \mathrm{~s}$ long. Since the signals were non-synchronous and delayed by up to $80 \mathrm{~s}$, the combined transient signal (average of about 60 cells) thus appeared to be of lower intensity but of more sustained duration. In addition, $15 \%$ of fibroblasts did not respond to factor Xa, reflecting a heterogeneous response. Catalytic site-inhibited DEGR-factor Xa did not elicit $\mathrm{Ca}^{2+}$ signals (Fig. 4A, left). Thrombin provoked an average increase in $\left[\mathrm{Ca}^{2+}\right]_{\mathrm{i}}$ of $285 \%$ above basal levels over the monitoring period $(P<0.05)$, which peaked at $410 \%$ above basal levels $40 \mathrm{~s}$ after stimulation (Fig. 4A, right). At the individual cell level, the thrombin response was similar in time and intensity to that of factor Xa, however, all fibroblasts responded in a synchronous fashion within $10 \mathrm{~s}$ of stimulation. Responses to the specific $\mathrm{PAR}_{1}$ agonist peptide TFLLR [28] were equivalent to those of thrombin, as previously observed in other cells $[20,44]$.

\section{Cytosolic $\mathrm{Ca}^{2+}$ signals in human lung fibroblasts desensitized with thrombin}

Following $\mathrm{PAR}_{1}$ activation, thrombin is known to cause a rapid and transient desensitization of $\mathrm{PAR}_{1}$ signaling responses [20]. We measured factor Xa-induced $\mathrm{Ca}^{2+}$ transients in thrombin-desensitized human fibroblasts. Fig. $4 \mathrm{~B}$ shows that pretreatment with thrombin $(25 \mathrm{nM})$ for 90 min totally desensitized cells to subsequent thrombin stimulation (complete inhibition, $P<0.01$ ). Fibroblasts 
A

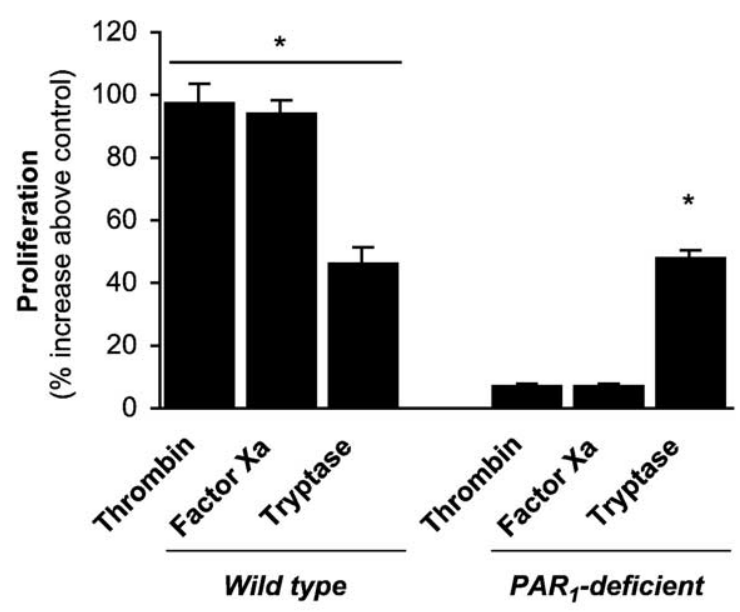

B

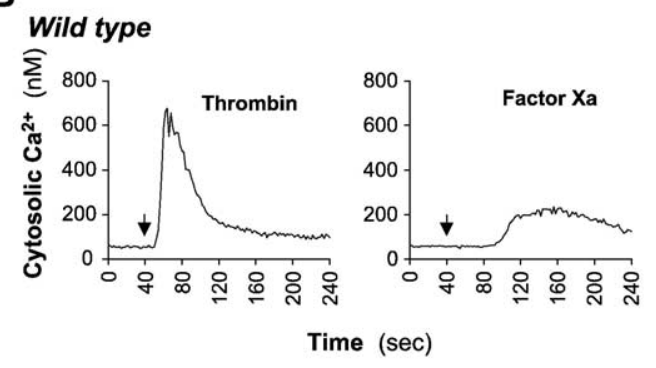

$P A R_{1}$-deficient
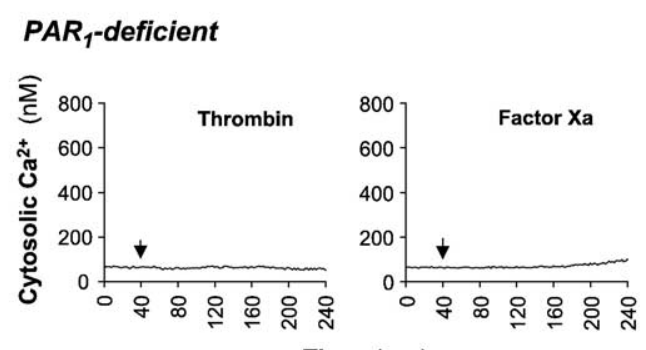

C

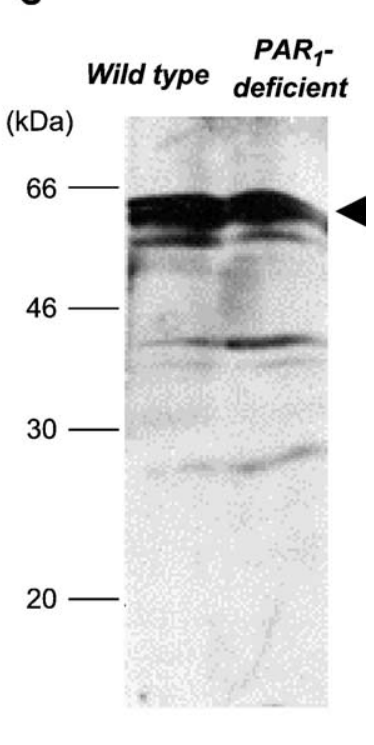

Fig. 3. $P_{1} R_{1}$ mediates factor Xa signaling and proliferation in mouse fibroblasts. (Panel A) $P_{A} R_{1}$-deficient mouse fibroblasts. Lung fibroblasts derived from wild-type and $\mathrm{PAR}_{1}$-deficient mice were grown to subconfluence, quiesced for $24 \mathrm{~h}$ and incubated for $48 \mathrm{~h} \mathrm{in} \mathrm{serum-free} \mathrm{control} \mathrm{medium,} \mathrm{thrombin} \mathrm{(} 25 \mathrm{nM}$ ), factor Xa $(25 \mathrm{nM})$ or tryptase $(25 \mathrm{nM})$. The fibroblast monolayer was fixed and stained with methylene blue which was quantified by spectrophotometry following elution. Data are expressed as mean of 12 replicates in $\%$ increase above control \pm SEM from a representative experiment that was repeated four times. ${ }^{*} P$ values $<0.01$ against control treatment. (Panel B) Calcium signaling. Subconfluent mouse lung fibroblasts were washed with HBS and incubated for 30 min with $2 \mu \mathrm{M}$ of the AM ester of the $\mathrm{Ca}^{2+}$ fluorescent indicator FURA-2. The fibroblast monolayers were washed twice with HBS and mounted on the stage of an inverted microscope fitted with an imaging system. Cytosolic-free $\mathrm{Ca}^{2+}$ was quantified by recording differential fluorescence after excitation of the cells at 340 and $380 \mathrm{~nm} .\left[\mathrm{Ca}^{2+}\right]_{\mathrm{i}}$ was monitored for $40 \mathrm{~s}$ before cells were exposed to factor Xa $(100 \mathrm{nM})$ or thrombin $(100 \mathrm{nM})$ and for $200 \mathrm{~s}$ thereafter. Arrowheads show time of proteinase delivery. Data are expressed as mean of three independent experiments, each with 10 to 12 cells monitored at each time

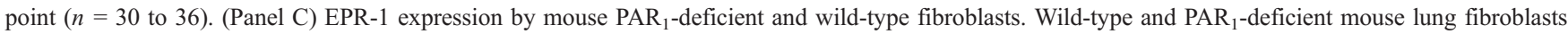
were grown to subconfluence, quiesced by serum deprivation and homogenized in SDS buffer and boiled. Aliquots of whole cell lysate normalized for total protein content $(80 \mu \mathrm{g})$ were electrophoresed on a $12 \%$ acrylamide gel under reducing conditions, transferred onto Immobilon membranes and immunoreacted with a rabbit polyclonal anti-EPR-1 antibody $(10 \mu \mathrm{g} / \mathrm{ml})$. EPR-1 appeared as a predominant band of about $65 \mathrm{kDa}$.

pretreated with thrombin also failed to respond to factor Xa (complete inhibition, $P<0.01$ ), consistent with the desensitization of factor Xa cytosolic $\mathrm{Ca}^{2+}$ signals.

\section{Cytosolic $\mathrm{Ca}^{2+}$ signals in human lung fibroblasts desensitized with factor Xa}

We next determined whether the signaling receptor for factor $\mathrm{Xa}$ is subject to homologous desensitization.
Fig. 4C shows that fibroblasts pretreated with factor Xa did not mobilize cytosolic $\mathrm{Ca}^{2+}$ in response to subsequent stimulation with factor $\mathrm{Xa}$ (complete inhibition, $P<$ 0.01). Moreover, fibroblasts pretreated with factor $\mathrm{Xa}$ showed greatly diminished responses to the $\mathrm{PAR}_{1}$ agonist TFLLR $(84 \%$ inhibition, $P<0.01)$, both in intensity and duration, suggesting that $\mathrm{PAR}_{1}$ is desensitized by factor $\mathrm{Xa}$ in fibroblasts in a manner reminiscent of thrombin [45]. 
A No pretreatment

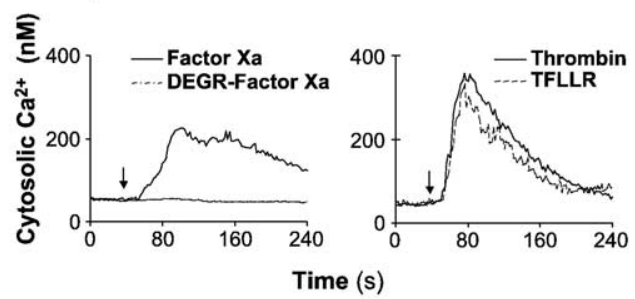

\section{B Pretreatment with thrombin}

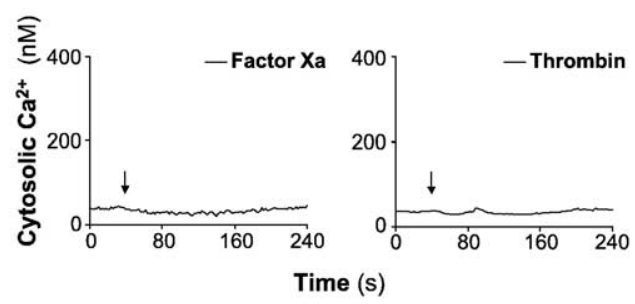

\section{Pretreatment with factor Xa}

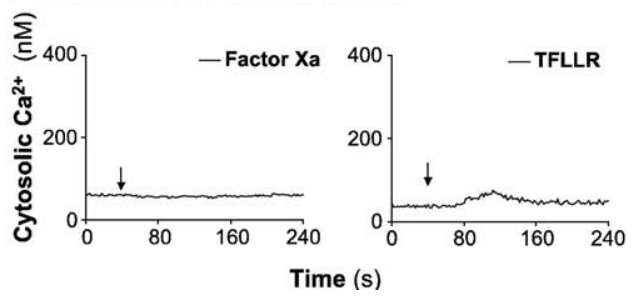

D

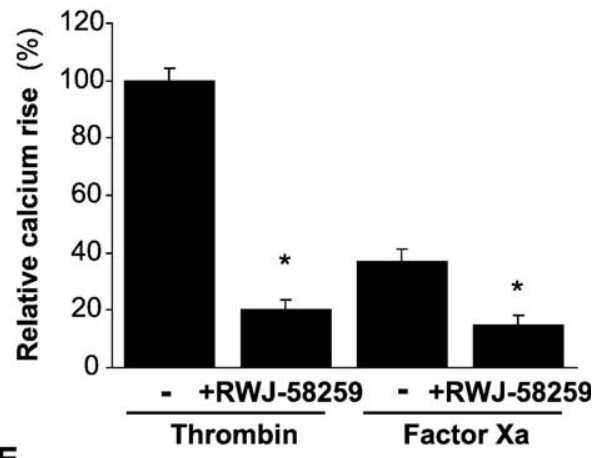

$\mathbf{E}$

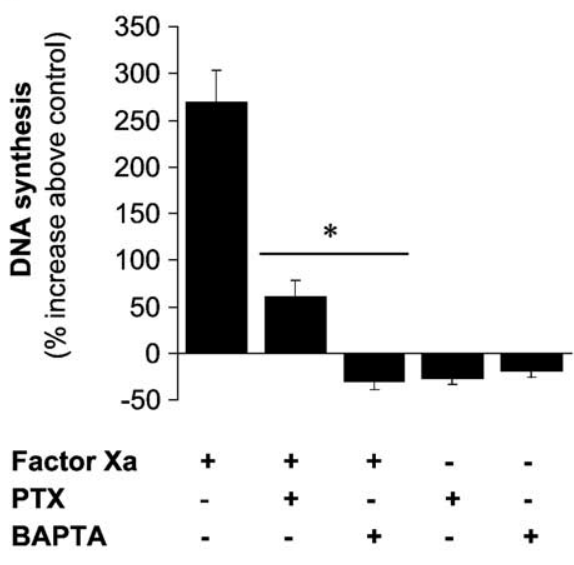

Fig. 4. $\mathrm{PAR}_{1}$ activation mediates factor Xa signaling in human and mouse fibroblasts. Subconfluent human fetal lung fibroblasts were exposed to serum-free control medium (Panel A), $25 \mathrm{nM}$ thrombin (Panel B) or $25 \mathrm{nM}$ factor Xa (Panel C) for 90 min. Treated fibroblasts were washed twice with HBS, Fura-2 loaded, and mounted on the stage of an inverted fluorescence microscope fitted with imaging system for cytosolic-free $\mathrm{Ca}^{2+} \mathrm{quantification}^{2}\left[\mathrm{Ca}^{2+}\right]_{\mathrm{i}}$ was then monitored for $40 \mathrm{~s}$ before cells were exposed to factor Xa $(100 \mathrm{nM})$, thrombin $(100 \mathrm{nM})$, or $100 \mu \mathrm{M}$ PAR $_{1}$ agonist peptide TFLLR, and for $200 \mathrm{~s}$ thereafter. Arrowheads show agonist delivery. Data are expressed as mean of three independent experiments, each with 10 to 12 cells monitored at each time point $(n=30$ to 36). (Panel D) Relative inhibition of cytosolic-free $\mathrm{Ca}^{2+}$ mobilization in human fetal lung fibroblast treated with thrombin, or factor Xa in the absence or presence of $1 \mu \mathrm{M}$ of the $\mathrm{PAR}_{1}$ antagonist RWJ-58259. Data are mean cytosolic-free $\mathrm{Ca}^{2+}$ rise in three independent experiments and expressed as \% of thrombin signal \pm SEM. $* P$ values $<0.01$ against treatment without RWJ-58259. (Panel E) Human fibroblast proliferation. Human fetal lung fibroblasts were grown to subconfluence, quiesced by serum deprivation, washed, and incubated with $100 \mu \mathrm{M}$ BAPTA-AM or $100 \mathrm{ng} / \mathrm{ml}$ PTX for $2 \mathrm{~h}$. At this point, $25 \mathrm{nM}$ factor Xa or control medium was added and the fibroblasts were further incubated for $16 \mathrm{~h}$. Fibroblasts were then incubated with $\left[{ }^{3} \mathrm{H}\right]$ thymidine $(0.5 \mu \mathrm{Ci} / \mathrm{well})$ for $4 \mathrm{~h}$, harvested, and incorporated radioactivity was quantified. Data are expressed as mean of six replicates in $\%$ increase above control \pm SEM from a representative experiment that was repeated three times. $* P$ values $<0.01$ against treatment with factor Xa alone.

Factor Xa cytosolic $\mathrm{Ca}^{2+}$ signals in the presence of the $P A R_{1}$ antagonist $R W J-58259$

To further invoke the role of $\mathrm{PAR}_{1}$ in mediating fibroblast responses to factor Xa, we examined the effect of a potent and selective PAR1 antagonist, RWJ-58259. Fig. 4D shows that thrombin and factor Xa elicited strong cytosolic $\mathrm{Ca}^{2+}$ rises in human lung fibroblasts pretreated with vehicle (HBS). However, pretreatment with RWJ58259 for $5 \mathrm{~min}$ inhibited thrombin and factor Xa signals by $80.0 \%(P<0.05)$ and $59.2 \%(P<0.05)$, respectively.

\section{Factor Xa mitogenesis is Pertussis toxin and BAPTA-sensitive}

To obtain additional supporting evidence that factor Xa modulates fibroblast function via $\mathrm{PAR}_{1}$, we further examined fibroblast proliferation in response to factor Xa. First, we found that the mitogenic effect of factor Xa at $50 \mathrm{nM}$ was exactly equivalent to that of thrombin at $50 \mathrm{nM}(P>$ 0.8 ), or to that of $25 \mathrm{nM}$ factor Xa in the presence of $25 \mathrm{nM}$ thrombin $(P>0.9)$, (methylene blue dye binding assay; data not shown). We next measured fibroblast proliferation in

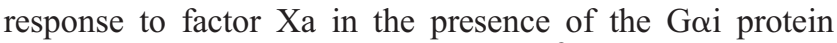
inhibitor, PTX, and the intracellular $\mathrm{Ca}^{2+}$ chelator, BAPTA [46], which are known to block $\mathrm{PAR}_{1}$ signaling in response to thrombin $[47,48]$. Fig. 4E shows that PTX and BAPTA completely inhibit the mitogenic effect of factor $\mathrm{Xa}$ on human fetal lung fibroblasts.

\section{Discussion}

Our previous report that factor $\mathrm{Xa}$ is mitogenic for human lung fibroblasts suggested that other coagulation cascade factors, and not just thrombin, may exert pro- 
fibrotic effects. In this study, we investigated further the effects of factor Xa on fibroblast procollagen production and proliferation, and focused on identifying its signaling receptor. We show for the first time that factor Xa stimulates procollagen production by both human and mouse fibroblasts. We also demonstrate that the effects of factor Xa on fibroblast calcium signaling, procollagen production, and proliferation are mediated predominantly by the proteinase receptor, $\mathrm{PAR}_{1}$.

\section{Factor Xa stimulates procollagen production by human and mouse fibroblasts}

We used both a luciferase-reporter gene assay and a biochemical method for the quantification of hydroxyproline and showed that factor $\mathrm{Xa}$ stimulates procollagen promoter activity and protein production. The effect of factor $\mathrm{Xa}$ on procollagen protein production was dosedependent and of similar magnitude to that observed with thrombin [17]. In contrast, other coagulation cascade proteinases, such as factor IXa, failed to increase procollagen production at concentrations thought to be generated in vivo [46]. This suggests that factor $\mathrm{Xa}$ and thrombin, which are activated during the final steps of the coagulation cascade, play a specific role in the regulation of fibroblast procollagen production that is not shared by upstream coagulation cascade proteinases.

We have previously shown that factor $\mathrm{Xa}$ induces human fibroblast proliferation via the upregulation of PDGF-AB production, release, and autocrine stimulation [25]. To determine the potential role of PDGF proliferation in factor Xa-stimulated fibroblast procollagen- $\alpha_{1}(\mathrm{I})$ promoter activity, we used a pan-specific anti-PDGF neutralizing antibody. This antibody completely blocked the effect of purified PDGF-AB in our procollagen promoter assay, but only blocked the effect of factor Xa by about $25 \%$. In addition, purified recombinant $\mathrm{PDGF}-\mathrm{AB}$ at optimal mitogenic concentrations only had a modest effect on procollagen$\alpha_{1}(\mathrm{I})$ gene transcription compared with factor Xa. Moreover, increased cell proliferation would have little or no effect on procollagen- $\alpha_{1}(\mathrm{I})$ promoter activity in our conditions as it is unlikely that the construct would be replicated during cell division. We and others have further shown that factor Xa acts independently of prothrombin activation in conditions of serum depletion and with careful washes of the cell layer at the onset of the experiments $[25,34,36]$. Together, these data imply that autocrine stimulation by PDGF and proliferation would only contribute marginally to procollagen gene expression induced by factor $\mathrm{Xa}$ in fibroblasts.

\section{$P A R_{1}$ mediates factor Xa stimulation of fibroblast procollagen promoter activity and procollagen production}

We used two highly specific factor Xa inhibitors, rTAP and ASN peptide, to show that the induction of procollagen$\alpha_{1}(\mathrm{I})$ promoter activity is chiefly dependent on factor Xa catalytic activity in fibroblasts. We further hypothesized that the proteolytic activation of the signaling receptor, $\mathrm{PAR}_{1}$, may mediate this effect. We obtained $\mathrm{PAR}_{1}$-deficient lung fibroblasts and showed that factor $\mathrm{Xa}$ had no significant effect on procollagen promoter activity and procollagen production in these cells, nor did the control $\mathrm{PAR}_{1}$ agonist thrombin. In contrast, factor $\mathrm{Xa}$ and thrombin stimulated a 3 -fold increase in procollagen- $\alpha_{1}$ (I) promoter activity $(n=$ $3, P<0.05)$, and a $45.5 \%$ increase in procollagen production $(n=3, P<0.05)$ in wild-type control fibroblasts. In contrast, TGF- $\beta_{1}$ (positive control) had similar effects on procollagen promoter activity (4-fold increase) in both wildtype and $\mathrm{PAR}_{1}$-deficient fibroblasts. This suggests that the stimulatory effects of factor $\mathrm{Xa}$ on fibroblast procollagen promoter activity, gene transcription and protein production are dependent on $\mathrm{PAR}_{1}$ expression and proteolytic activation. $P A R_{1}$ mediates factor Xa signaling and proliferation in
mouse fibroblasts

We have previously shown that the mitogenic effect of factor $\mathrm{Xa}$ for fibroblasts is dependent on its proteolytic activity, but the signaling receptor remained unknown [25]. Here, we provide compelling genetic evidence that $\mathrm{PAR}_{1}$ plays an essential role in the activation of fibroblasts by factor Xa. Indeed, $\mathrm{PAR}_{1}$-deficient mouse lung fibroblasts fail to either proliferate or mobilize cytosolic $\mathrm{Ca}^{2+}$ in response to factor $\mathrm{Xa}$, whereas these cells proliferate in response to mast cell tryptase [49,50]. Although it has previously been shown that factor $\mathrm{Xa}$ can activate $\mathrm{PAR}_{1}$ in transfected cell lines [26,27], this is to our knowledge the first report that $\mathrm{PAR}_{1}$ is necessary for factor Xa-stimulated $\mathrm{Ca}^{2+}$ signaling and function in fibroblasts.

The only previous observations in normal differentiated cells were obtained using vascular smooth muscle cells [51] and endothelial cells [52,53]. These studies show that $\mathrm{PAR}_{2}$, rather than $\mathrm{PAR}_{1}$, mediates factor $\mathrm{Xa}$ signaling in the vasculature and are supported by reports that factor $\mathrm{Xa}$ evokes aorta relaxation via $\mathrm{PAR}_{2}$ activation [54]. Our results therefore show for the first time that $\mathrm{PAR}_{1}$ is the main transducer of factor Xa signaling in fibroblasts, in contrast with the vasculature where $\mathrm{PAR}_{2}$ plays the major role.

\section{$P A R_{1}$ mediates factor $X a$ signaling and proliferation in human fibroblasts}

We aimed to further characterize the specific role of $\mathrm{PAR}_{1}$ in the activation of human fibroblasts by factor $\mathrm{Xa}$, and examined cytosolic $\mathrm{Ca}^{2+}$ signals in human fetal lung fibroblasts. Factor Xa, like thrombin and the highly specific $\mathrm{PAR}_{1}$ agonist peptide, TFLLR, was able to stimulate strong transient cytosolic $\mathrm{Ca}^{2+}$ signals. However, catalytically inhibited factor Xa, DEGR-factor Xa, failed to elicit $\mathrm{Ca}^{2+}$ signals in human fibroblasts, suggesting a critical role for factor Xa proteolytic activity. One noticeable difference 
between factor $\mathrm{Xa}$ signals and those of thrombin and TFLLR is the characteristic delay in its onset seen in human and mouse fibroblasts. The delayed kinetics of $\mathrm{PAR}_{1}$ cleavage by Xa, previously observed in HeLa cells [27], are difficult to explain fully at this time, but could stem from a rate limitation arising from the requirement for protease binding to the cell surface before proteolytic activation of $\mathrm{PAR}_{1}$. Thrombin, which directly interacts with specific, high-affinity hirudin-like regions of $\mathrm{PAR}_{1}$ [19], could show faster binding kinetics than factor $\mathrm{Xa}$, which lacks known specific $\mathrm{PAR}_{1}$ interaction mechanisms, as discussed by Riewald et al. [27].

Following $\mathrm{PAR}_{1}$ activation, a period of receptor desensitization follows until new receptors appear at the cell surface [20]. This enabled us to specifically abrogate $\mathrm{PAR}_{1}$ responses and evaluate potential agonists in our human fibroblasts. Thrombin elicited immediate $\mathrm{Ca}^{2+}$ signals that were completely desensitized by thrombin pretreatment, as previously reported for human kidney cells [55], platelets [56], and megakaryocytic cells [38]. $\mathrm{PAR}_{1}$ desensitization with thrombin abrogated subsequent factor $\mathrm{Xa}$ signals (heterologous desensitization). Similarly, desensitization with factor $\mathrm{Xa}$ blocked subsequent factor $\mathrm{Xa}$ signals (homologous desensitization). Moreover, desensitization with factor $\mathrm{Xa}$ prevented subsequent signaling with the highly specific $\mathrm{PAR}_{1}$ agonist peptide TFLLR [28]. These data suggest that factor Xa signaling is sensitive to specific $\mathrm{PAR}_{1}$ desensitization, and that factor $\mathrm{Xa}$ desensitizes subsequent $\mathrm{PAR}_{1}$-mediated responses. To further demonstrate the critical role of $\mathrm{PAR}_{1}$ in factor Xa signaling, we used the specific $\mathrm{PAR}_{1}$ antagonist RWJ-58259 which prevents $\mathrm{PAR}_{1}$ signaling without altering other proteinase receptor responses [29]. These studies would allow us to eliminate the possibility that $\mathrm{PAR}_{1}$ may in fact be desensitized by indirect mechanisms [57] rather than direct factor $\mathrm{Xa}$ activation. Fibroblast pretreatment with $1 \mu \mathrm{M}$ RWJ-58259 prevented thrombin signaling by $80 \%$, and factor Xa signaling by about $60 \%$. When taken altogether, these experiments point toward a central role for $\mathrm{PAR}_{1}$ in factor Xa signaling in human lung fibroblasts, and specific $\mathrm{PAR}_{1}$ inhibition suggests that over two thirds of factor $\mathrm{Xa}$ signaling in fibroblasts are dependent upon $\mathrm{PAR}_{1}$ activation.

Additional supportive evidence that factor Xa signaling is mediated by $\mathrm{PAR}_{1}$ in human fibroblasts was obtained in experiments showing that factor Xa-induced proliferation is dependent on Goi protein activation and cytosolic $\mathrm{Ca}^{2+}$ mobilization, two features of PAR signaling [58]. In addition, the mitogenic effects of factor $\mathrm{Xa}$ and thrombin were equivalent at equal concentrations, and their effects were strictly additive, suggesting that the proteolytic activity of thrombin and factor Xa can be substituted to activate a common signaling pathway and directly stimulate fibroblast function. Taken together, our data in human and mouse lung fibroblasts provide compelling evidence that factor $\mathrm{Xa}$ activates $\mathrm{PAR}_{1}$ to stimulate fibroblast intracellular $\mathrm{Ca}^{2+}$ signals, procollagen production and proliferation. This is the first report that $\mathrm{PAR}_{1}$ is the main endogenous signaling receptor for factor $\mathrm{Xa}$ in human fetal fibroblasts where $\mathrm{PAR}_{2}, \mathrm{PAR}_{3}$, and $\mathrm{PAR}_{4}$ are known to be expressed [49] (and data not shown).

\section{Role of other receptors in factor Xa signaling responses in fibroblasts}

In the absence of $\mathrm{PAR}_{1}$ expression, factor Xa stimulated no significant increase in fibroblast proliferation, procollagen promoter activity, or protein production, suggesting that $\mathrm{PAR}_{1}$ is necessary to mediate the effects of factor $\mathrm{Xa}$ on fibroblast function. However, factor $\mathrm{Xa}$ was able to stimulate transient $\mathrm{Ca}^{2+}$ signals in about $10 \%$ of $\mathrm{PAR}_{1}$ deficient mouse fibroblasts, and in about $30 \%$ of human fetal fibroblasts after specific $\mathrm{PAR}_{1}$ inhibition. It is likely that some of the remaining detectable signals are mediated by an independent receptor. Since factor Xa binds to EPR1 or activates $\mathrm{PAR}_{2}$ in cell types such as smooth muscle and endothelial cells, it is possible that factor Xa activates these receptors in fibroblasts. It is known that factor $\mathrm{Xa}$ does not cleave EPR-1 [59] but that catalytically inactive DEGR-factor Xa binds EPR-1 in a similar way to factor $\mathrm{Xa}$ [60]. We have previously shown that EPR-1 ligation by factor $\mathrm{Xa}$ enhances, but is not sufficient to stimulate fibroblast proliferation [25]. We also showed that the effects of factor $\mathrm{Xa}$ on procollagen production (this work) and proliferation [25] depend on factor Xa catalytic activity, even in the presence of EPR-1. Together, these observations suggest that EPR-1 ligation may play an accessory role in the regulation of fibroblast function by factor $\mathrm{Xa}$ in vitro. Since $\mathrm{PAR}_{2}$ is activated by factor $\mathrm{Xa}$ in other cell types and expressed by human fetal lung fibroblasts [49], $\mathrm{PAR}_{2}$ may mediate a proportion of factor Xa-dependent signaling. Finally, it is tempting to speculate that the expression of additional coagulation cascade proteinase receptors such as tissue factor with the simultaneous presence of small amounts of factor VIIa may increase the effects of factor Xa on fibroblasts, as they do for factor $\mathrm{Xa}$ in HeLa cells [27]. However, $\mathrm{PAR}_{1}$-deficient fibroblast studies suggest that the signals mediated by putative additional receptors are not sufficient to engage human or mouse fibroblasts proliferation or procollagen production.

\section{Summary and conclusion}

This is, to our knowledge, the first report that factor $\mathrm{Xa}$ or any coagulation cascade proteinase other than thrombin, stimulates fibroblast procollagen production. This is also the first study demonstrating that $\mathrm{PAR}_{1}$ is the major signaling receptor mediating the effects of factor $\mathrm{Xa}$ on fibroblast procollagen production and proliferation, implying that factor Xa activates and exerts its cellular effects via distinct PAR receptors in the vasculature and the lung parenchyma. This information is critical to our understanding of tissue 
repair mechanisms and lends support to the emergence of $\mathrm{PAR}_{1}$ as a dominant sensor of multiple signals elicited by coagulation cascade proteinases in fibroblasts. Our observations may take particular significance in the design of antifibrotic therapies. $\mathrm{PAR}_{1}$ and the signaling pathways triggered by both factor $\mathrm{Xa}$ and thrombin may represent attractive targets for interfering with tissue fibrosis while preserving their role in blood coagulation.

\section{Acknowledgments}

The authors gratefully acknowledge generous support from Johnson and Johnson Medical-UK and the Wellcome Trust (Programme Grant No 051154). Calcium measurements were performed in the laboratory of Stephen Bolsover, Department of Physiology, University College London (UK), and supported by grants from the Wellcome Trust, Action Research, the Biotechnology and Biological Sciences Research Council and the Medical Research Council.

\section{References}

[1] R.P. Marshall, R.J. McAnulty, G.J. Laurent, The pathogenesis of pulmonary fibrosis: is there a fibrosis gene? Int. J. Biochem. Cell Biol. 29 (1997) 107-120.

[2] M.A. Cunningham, E. Rondeau, X. Chen, S.R. Coughlin, S.R. Holdsworth, P.G. Tipping, Protease-activated receptor 1 mediates thrombin-dependent, cell-mediated renal inflammation in crescentic glomerulonephritis, J. Exp. Med. 191 (3) (2000) 455-462.

[3] F. Marra, Chemokines in liver inflammation and fibrosis, Front. Biosci. 7 (2002) d1899-d1914.

[4] H.A. Chapman, C.L. Allen, O.L. Stone, Abnormalities in pathways of alveolar fibrin turnover among patients with interstitial lung disease, Am. Rev. Respir. Dis. 133 (1986) 437-443.

[5] I. Kotani, A. Sato, H. Hayakawa, T. Urano, Y. Takada, A. Takada, Increased procoagulant and antifibrinolytic activities in the lungs with idiopathic pulmonary fibrosis, Thromb. Res. 77 (1995) 493-504.

[6] S. Idell, A.P. Mazar, P. Bitterman, S. Mohla, A.L. Harabin, Fibrin turnover in lung inflammation and neoplasia, Am. J. Respir. Crit. Care Med. 163 (2001) 578-584.

[7] N.A. Hernandez-Rodriguez, A.D. Cambrey, N.K. Harrison, R.C. Chambers, A.J. Gray, A.M. Southcott, R.M. duBois, C.M. Black, M.F. Scully, R.J. McAnulty, G.J. Laurent, Role of thrombin in pulmonary fibrosis, Lancet 346 (1995) 1071-1073.

[8] S. Idell, K. Gonzalez, H. Bradford, C.K. MacArthur, A.M. Fein, R.J. Maunder, J.G. Garcia, D.E. Griffith, J. Weiland, T.R. Martin, Procoagulant activity in bronchoalveolar lavage in the adult respiratory distress syndrome. Contribution of tissue factor associated with factor VII, Am. Rev. Respir. Dis. 136 (1987) 1466-1474.

[9] S. Idell, K.K. Gonzalez, C.K. MacArthur, C. Gillies, P.N. Walsh, J. McLarty, R.S. Thrall, Bronchoalveolar lavage procoagulant activity in bleomycin-induced lung injury in marmosets. Characterization and relationship to fibrin deposition and fibrosis, Am. Rev. Respir. Dis. 136 (1987) $124-133$.

[10] A. Kumar, K.B. Koenig, A.R. Johnson, D.S. Fair, S. Idell, Inhibition of factor Xa-mediated procoagulant activity of human lung fibroblasts and pleural mesothelial cells, Eur. Respir. J. 8 (1995) 2038-2045.

[11] E.W. Davie, K. Fujikawa, W. Kisiel, The coagulation cascade: initiation, maintenance, and regulation, Biochemistry 30 (1991) $10363-10370$.
[12] E.W. Davie, Biochemical and molecular aspects of the coagulation cascade, Thromb. Haemost. 74 (1995) 1-6.

[13] W. Kirschstein, D.L. Heene, Fibrinolysis inhibition in acute respiratory distress syndrome, Scand. J. Clin. Lab. Invest., Suppl. 178 (1985) 87-94.

[14] K.E. Dawes, A.J. Gray, G.J. Laurent, Thrombin stimulates fibroblast chemotaxis and replication, Eur. J. Cell Biol. 61 (1993) 126-130.

[15] T. Ohba, Y. Takase, M. Ohhara, R. Kasukawa, Thrombin in the synovial fluid of patients with rheumatoid arthritis mediates proliferation of synovial fibroblast-like cells by induction of platelet derived growth factor, J. Rheumatol. 23 (1996) 1505-1511.

[16] T. Ohba, J.K. McDonald, R.M. Silver, C. Strange, E.C. LeRoy, A. Ludwicka, Scleroderma bronchoalveolar lavage fluid contains thrombin, a mediator of human lung fibroblast proliferation via induction of platelet-derived growth factor alpha-receptor, Am. J. Respir. Cell Mol. Biol. 10 (1994) 405-412.

[17] R.C. Chambers, K. Dabbagh, R.J. McAnulty, A.J. Gray, O.P. Blanc-Brude, G.J. Laurent, Thrombin stimulates fibroblast procollagen production via proteolytic activation of protease-activated receptor 1, Biochem. J. 333 (1998) 121-127.

[18] D.C. Howell, N.R. Goldsack, R.P. Marshall, R.J. McAnulty, R. Starke, G. Purdy, G.J. Laurent, R.C. Chambers, Direct thrombin inhibition reduces lung collagen, accumulation, and connective tissue growth factor mRNA levels in bleomycin-induced pulmonary fibrosis, Am. J. Pathol. 159 (2001) 1383-1395.

[19] S.R. Coughlin, How the protease thrombin talks to cells, Proc. Natl. Acad. Sci. U. S. A. 96 (1999) 11023-11027.

[20] A.J. Connolly, H. Ishihara, M.L. Kahn, R.V. Farese Jr., S.R. Coughlin, Role of the thrombin receptor in development and evidence for a second receptor, Nature 381 (1996) 516-519.

[21] C.J. Molloy, J.E. Pawlowski, D.S. Taylor, C.E. Turner, H. Weber, M. Peluso, Thrombin receptor activation elicits rapid protein tyrosine phosphorylation and stimulation of the raf-1/MAP kinase pathway preceding delayed mitogenesis in cultured rat aortic smooth muscle cells: evidence for an obligate autocrine mechanism promoting cell proliferation induced by G-protein-coupled receptor agonist, J. Clin. Invest. 97 (1996) 1173-1183.

[22] R.C. Chambers, P. Leoni, O.P. Blanc-Brude, D.E. Wembridge, G.J. Laurent, Thrombin is a potent inducer of connective tissue growth factor production via proteolytic activation of protease-activated receptor-1, J. Biol. Chem. 275 (2000) 35584-35591.

[23] D.C. Howell, G.J. Laurent, R.C. Chambers, Role of thrombin and its major cellular receptor, protease-activated receptor-1, in pulmonary fibrosis, Biochem. Soc. Trans. 30 (2002) 211-216.

[24] R.C. Chambers, G.J. Laurent, Coagulation cascade proteases and tissue fibrosis, Biochem. Soc. Trans. 30 (2002) 194-200.

[25] O. Blanc-Brude, R.C. Chambers, P. Leoni, W.A. Dik, G.J. Laurent, Factor $\mathrm{Xa}$ is a fibroblast mitogen via binding to effector-cell protease receptor-1 and autocrine release of PDGF, Am. J. Physiol.: Cell Physiol. 281 (2001) C681-C689.

[26] M. Riewald, W. Ruf, Mechanistic coupling of protease signaling and initiation of coagulation by tissue factor, Proc. Natl. Acad. Sci. U. S. A. 98 (2001) $7742-7747$.

[27] M. Riewald, V.V. Kravchenko, R.J. Petrovan, P.J. O’Brien, L.F. Brass, R.J. Ulevitch, W. Ruf, Gene induction by coagulation factor Xa is mediated by activation of protease-activated receptor 1, Blood 97 (2001) 3109-3116.

[28] M.D. Hollenberg, M. Saifeddine, B. al-Ani, A. Kawabata, Proteinaseactivated receptors: structural requirements for activity, receptor crossreactivity, and receptor selectivity of receptor-activating peptides, Can. J. Physiol. Pharmacol. 75 (1997) 832-841.

[29] C.K. Derian, B.P. Damiano, M.F. Addo, A.L. Darrow, M.R. D'Andrea, M. Nedelman, H.C. Zhang, B.E. Maryanoff, P. Andrade-Gordon, Blockade of the thrombin receptor proteaseactivated receptor-1 with a small-molecule antagonist prevents thrombus formation and vascular occlusion in nonhuman primates, J. Pharmacol. Exp. Ther. 304 (2003) 855-861. 
[30] S.P. Jordan, S.S. Mao, S.D. Lewis, J.A. Shafer, Reaction pathway for inhibition of blood coagulation factor $\mathrm{Xa}$ by tick anticoagulant peptide, Biochemistry 31 (1992) 5374-5380.

[31] N. Ohta, M. Brush, J.W. Jacobs, Interaction of antistasin-related peptides with factor Xa: identification of a core inhibitory sequence, Thromb. Haemost. 72 (1994) 825-830.

[32] M.H. Oliver, N.K. Harrison, J.E. Bishop, P.J. Cole, G.J. Laurent, A rapid and convenient assay for counting cells cultured in microwell plates: application for assessment of growth factors, J. Cell Sci. 92 (1989) 513-518.

[33] C. Adida, P.L. Crotty, J. McGrath, D. Berrebi, J. Diebold, D.C. Altieri, Developmentally regulated expression of the novel cancer antiapoptosis gene survivin in human and mouse differentiation, Am. J. Pathol. 152 (1998) 43-49.

[34] E. Camerer, W. Huang, S.R. Coughlin, Tissue factor- and factor Xdependent activation of protease-activated receptor 2 by factor VIIa, Proc. Natl. Acad. Sci. U. S. A. 97 (2000) 5255-5260.

[35] G. Grynkiewicz, M. Poenie, R.Y. Tsien, A new generation of Ca2+ indicators with greatly improved fluorescence properties, J. Biol. Chem. 260 (1985) 3440-3450.

[36] A. Papapetropoulos, P. Piccardoni, G. Cirino, M. Bucci, R. Sorrentino, C. Cicala, K. Johnson, V. Zachariou, W.C. Sessa, D.C. Altieri, Hypotension and inflammatory cytokine gene expression triggered by factor Xa-nitric oxide signaling, Proc. Natl. Acad. Sci. U. S. A. 95 (1998) 4738-4742.

[37] C.A. Ellis, C. Tiruppathi, R. Sandoval, W.D. Niles, A.B. Malik, Time course of recovery of endothelial cell surface thrombin receptor (PAR1) expression, Am. J. Physiol. 276 (1999) C38-C45.

[38] J.A. Hoxie, M. Ahuja, E. Belmonte, S. Pizarro, R. Parton, L.F. Brass, Internalization and recycling of activated thrombin receptors, J. Biol. Chem. 268 (1993) 13756-13763.

[39] J.S. Campa, R.J. McAnulty, G.J. Laurent, Application of highpressure liquid chromatography to studies of collagen production by isolated cells in culture, Anal. Biochem. 186 (1990) 257-263.

[40] R.J. McAnulty, J.S. Campa, A.D. Cambrey, G.J. Laurent, The effect of transforming growth factor beta on rates of procollagen synthesis and degradation in vitro, Biochim. Biophys. Acta 1091 (1991) 231-235.

[41] S.A. Jimenez, J. Varga, A. Olsen, L. Li, A. Diaz, J. Herhal, J. Koch, Functional analysis of human alpha 1(I) procollagen gene promoter. Differential activity in collagen-producing and -nonproducing cells and response to transforming growth factor beta 1, J. Biol. Chem. 269 (1994) 12684-12691.

[42] Q. Wang, R. Raghow, Okadaic acid-induced transcriptional downregulation of type I collagen gene expression is mediated by protein phosphatase 2A, Mol. Cell. Biochem. 158 (1996) 33-42.

[43] S.L. Hart, L. Collins, K. Gustafsson, J.W. Fabre, Integrin-mediated transfection with peptides containing arginine-glycine-aspartic acid domains, Gene Ther. 4 (1997) 1225-1230.

[44] S.R. Hammes, S.R. Coughlin, Protease-activated receptor-1 can mediate responses to SFLLRN in thrombin-desensitized cells: evidence for a novel mechanism for preventing or terminating signaling by PAR1's tethered ligand, Biochemistry 38 (1999) 2486-2493.

[45] R.J. Santulli, C.K. Derian, A.L. Darrow, K.A. Tomko, A.J. Eckardt, M. Seiberg, R.M. Scarborough, P. Andrade-Gordon, Evidence for the presence of a protease-activated receptor distinct from the thrombin receptor in human keratinocytes, Proc. Natl. Acad. Sci. U. S. A. 92 (1995) 9151-9155.

[46] R.Y. Tsien, New calcium indicators and buffers with high selectivity against magnesium and protons: design, synthesis, and properties of prototype structures, Biochemistry 19 (1980) 2396-2404.

[47] M.F. Crouch, L. Simson, The G-protein G(i) regulates mitosis but not DNA synthesis in growth factor-activated fibroblasts: a role for the nuclear translocation of G(i), FASEB J. 11 (1997) 189-198.

[48] G. Baffy, L. Yang, S. Raj, D.R. Manning, J.R. Williamson, G protein coupling to the thrombin receptor in Chinese hamster lung fibroblasts, J. Biol. Chem. 269 (1994) 8483-8487.

[49] I.A. Akers, M. Parsons, M.R. Hill, M.D. Hollenberg, S. Sanjar, G.J. Laurent, R.J. McAnulty, Mast cell tryptase stimulates human lung fibroblast proliferation via protease-activated receptor-2, Am. J. Physiol.: Lung Cell Mol. Physiol. 278 (2000) L193-L201.

[50] H. Mirza, V.A. Schmidt, C.K. Derian, J. Jesty, W.F. Bahou, Mitogenic responses mediated through the proteinase-activated receptor- 2 are induced by expressed forms of mast cell alpha- or beta-tryptases, Blood 90 (1997) 3914-3922.

[51] B.H. Koo, K.H. Chung, K.C. Hwang, D.S. Kim, Factor Xa induces mitogenesis of coronary artery smooth muscle cell via activation of PAR-2, FEBS Lett. 523 (2002) 85-89.

[52] F. Bono, P. Schaeffer, J.P. Herault, C. Michaux, A.L. Nestor, J.C. Guillemot, J.M. Herbert, Factor Xa activates endothelial cells by a receptor cascade between EPR-1 and PAR-2, Arterioscler. Thromb. Vasc. Biol. 20 (2000) E107-E112.

[53] E. Camerer, H. Kataoka, M. Kahn, K. Lease, S.R. Coughlin, Genetic evidence that protease-activated receptors mediate factor Xa signaling in endothelial cells, J. Biol. Chem. 277 (2002) 16081-16087.

[54] A. Kawabata, R. Kuroda, Y. Nakaya, K. Kawai, H. Nishikawa, N. Kawao, Factor Xa-evoked relaxation in rat aorta: involvement of PAR-2, Biochem. Biophys. Res. Commun. 282 (2001) 432-557.

[55] A. Kawabata, M. Saifeddine, B. Al-Ani, L. Leblond, M.D. Hollenberg, Evaluation of proteinase-activated receptor-1 (PAR1) agonists and antagonists using a cultured cell receptor desensitization assay: activation of PAR2 by PAR1-targeted ligands, J. Pharmacol. Exp. Ther. 288 (1999) 358-370.

[56] M.L. Kahn, M. Nakanishi-Matsui, M.J. Shapiro, H. Ishihara, S.R. Coughlin, Protease-activated receptors 1 and 4 mediate activation of human platelets by thrombin, J. Clin. Invest. 103 (1999) 879-887.

[57] J. Trejo, Protease-activated receptors: new concepts in regulation of G protein-coupled receptor signaling and trafficking, J. Pharmacol. Exp. Ther. 307 (2003) 437-442.

[58] J. Trejo, A.J. Connolly, S.R. Coughlin, The cloned thrombin receptor is necessary and sufficient for activation of mitogen-activated protein kinase and mitogenesis in mouse lung fibroblasts. Loss of responses in fibroblasts from receptor knockout mice, J. Biol. Chem. 271 (1996) $21536-21541$.

[59] G. Ambrosini, D.C. Altieri, Molecular dissection of effector cell protease receptor-1 recognition of factor Xa. Assignment of critical residues involved in antibody reactivity and ligand binding, J. Biol. Chem. 271 (1996) 1243-1248

[60] G. Ambrosini, J. Plescia, K.C. Chu, K.A. High, D.C. Altieri, Activation-dependent exposure of the inter-EGF sequence Leu83Leu88 in factor Xa mediates ligand binding to effector cell protease receptor-1, J. Biol. Chem. 272 (1997) 8340-8345. 